\title{
Job Involvement or Affective Commitment: A Sensitivity Analysis Study of Apathetic Employee Mobility
}

\author{
John C. Hafer and Thomas N. Martin \\ University of Nebraska at Omaha
}

\begin{abstract}
Apathetic employees constitute one of four employee categories in Blau and Boal's (1987) model. Six sensitivity analyses were applied to create positive and negative changes in the measurement scores on job involvement and affective commitment of 553 employees to determine which variable produced the greatest Apathetic employee mobility. While changing both variables simultaneously created the greatest movement, on an individual basis, changing affective commitment produced greater Apathetic employee mobility than changing job involvement. The managerial implications of these findings are discussed.
\end{abstract}

\section{Introduction}

Understanding, predicting, and improving employee behaviors are major aspects of a manager's job. Managers often try to influence work-related attitudes in order to create behavioral changes, relying on moderating variables such as the importance of the attitude, its specificity, its accessibility, whether social pressures exist between attitudes, and whether employees have direct experience with the attitude to impact what employees behaviorally do. This attitude-behavior relationship asserts that attitudes significantly predict future behavior by taking the previously mentioned moderating variables into account (Ajzen, 2001, 1996; Kraus, 1995; Sutton, 1998). To actually implement their decisions to influence employee attitudes, managers often enact various organizational and personal influence tactics. Most, if not all of these decisions are made under uncertainty and the effectiveness of some of these decisions remain questionable even after implementation. An alternative to the previously-mentioned active engagement process is the use of sensitivity analysis in which the user is allowed to play "what if," simulated games with a model to better understand the model's relationships and inherent tradeoffs (Fischoff, Slovic, \& Lichtenstein, 1979; Liberatore \& Nydick, 2003; Walker \& Fox-Rushby, 2001; Wallace, 2000).

Job involvement and affective commitment have each received attention as workrelated attitudes and subsequent predictors of work-related outcomes such as intentions to leave an organization (Freund, 2005), professional commitment and ethical behavior (Leong, Huang, \& Hsu, 2003), psychological ownership for the organization and performance (Van Dyne \& Pierce, 2004), lower role conflict and role ambiguity (Clinebell \& Shadwick, 2005), and an employee's readiness for change (Madsen, Miller, \& John, 2005). Their complementary role has been examined in a model by Blau and Boal (1987) in which one finds four different types of employee categories: Institutional Stars (hereafter called Stars), Lone Wolves, Corporate Citizens, and Apathetics. 
Each of these employee categories is predicted by Blau and Boal (1987) to increase our understanding of task-related effort as well as the withdrawal behaviors of turnover and absenteeism. Employees with high levels of job involvement identify with and care about their jobs, whereas, employees with high levels of affective commitment feel positively about their organization and wish to remain a member in it. Consequently, employees with high levels of both attitudes should be the most behaviorally motivated because they are both attracted by their job and their organization. Alternatively, working conditions and the organization can be perceived as alienating and employees, over time, may distance and separate themselves from their jobs and their organization and become apathetic employees (Drummond \& Chell, 2001). The model has been found to predict various work-related outcomes such as job performance, absenteeism, turnover and motivational effort (Blau, 1986; Blau \& Boal, 1989; Casal, 1996; Elliott \& Hall, 1994; Griffeth, Gaertner \& Sager, 1999; Huselid, 1991; Martin \& Hafer, 1995; McElroy, Morrow, Crum \& Dooley, 1995), however, no research has been conducted to examine how changes in the two attitudes produce changes in the four employee categories. Thus, the main purpose of this study is to apply sensitivity analysis to the employee categorization model created by Blau and Boal (1987). There are two underlying pragmatic purposes for applying sensitivity analysis to the model, however, these will be explained after the model is more fully presented in a later section.

$\underline{\text { The Attitudinal Variables: Affective Commitment and Job Involvement }}$

Organizational commitment has widely been defined as identification and involvement with the organization via believing in the organization's values and goals, exerting effort on behalf of the organization, and desiring to remain with the organization (Mowday, Steers, \& Porter, 1979). Meyer and Allen (1991) and Allen and Meyer (1990) presented evidence suggesting commitment consists of affective commitment, continuance commitment, and normative commitment. In essence, Meyer and Allen's (1991) affective commitment is similar to Mowday et al.'s (1979) original construct. Affective commitment represents the type of commitment utilized in the Blau and Boal (1987) model.

Job involvement is how people see their jobs as both a relationship with the working environment, the job itself and how their work and life are commingled. Having low job involvement contributes to employees' feelings of alienation of purpose, alienation in the organization or feeling of separation between what the employees see as their "life" and the job they do. Work alienation and job involvement are correlated with one another (Hirschfeld \& Field, 2000; Rabinowitz \& Hall, 1981).

\section{Employee Categories}

The employee categorization utilized in this study is from the Blau and Boal (1987) model. Their base model is formulated by partitioning job involvement and affective commitment into high and low categories based on median splits of the questionnaire scales and then combining them into four employee categories: Stars, Lone Wolves, Corporate Citizens, and Apathetics. 
The modeling parameters for Stars are that they have high affective commitment and high job involvement. Their work is important to their self-image and behaviorally, they exert a high level of personal task-related effort and a high level of group maintenance effort to help maintain commitment to the organization (Blau \& Boal, 1987). Star employees are often used as role models for other employees, are upwardly mobile in the organization, and are supported by powerful coalitions or individuals within the organization (Griffeth et al., 1999).

Lone Wolves have modeling parameters that include high job involvement, but low affective commitment. Their work and/or job are important to them, but they do not identify strongly with their organization. They are especially sensitive to either the satisfaction facet of their work environment that directly involves their work or to the facets reflecting the importance of their work. Behaviorally, they are low on organizational loyalty, but high on commitment to specialized role skills and may isolate themselves from their company and coworkers in the pursuit of their work/professional goals, however, these behaviors are generally not viewed as antisocial or antiorganizational (Griffeth et. al., 1999).

Corporate citizens are modeled by having low job involvement, but high affective commitment. They identify strongly with the organization and its goals, but because of low job involvement, they do not readily identify with their job or see it as a factor in their self-identity. Behaviorally, they provide continuity and cohesion and are sometimes seen as employees who cooperate spontaneously to achieve organizational objectives that go beyond role specification (Blau \& Boal, 1987; Griffeth et. al., 1999).

Finally, the modeling characteristics of Apathetic employees includes low job involvement and low affective commitment. They may have been once highly motivated by their jobs and strongly committed to their organization, but are now indifferent to both. Behaviorally, they are prone to practice calculative behavior. Exert minimal work effort just enough to maintain organizational membership and will try to leave the organization whenever alternative opportunities become available and present high extrinsic rewards (Griffeth et al., 1999). Figure 1 displays Blau and Boal's (1987) basic model.

\section{Figure 1 \\ Blau and Boal's Employee Model}

\begin{tabular}{l|l|l|} 
& Low Job Involvement & High Job Involvement \\
\cline { 2 - 3 } High Affective Commitment & Corporate Citizens & Institutional Stars \\
\hline Low Affective Commitment & Apathetics & Lone Wolves \\
\hline
\end{tabular}

As previously mentioned, there are two underlying pragmatic purposes for applying sensitivity analysis to this model. From a managerial perspective in which managers would like to see employee behavior make overall positive contributions to the job and/or organization, Apathetics, when compared to the other three employee categories 
generally make less positive behavioral contributions. Apathetics, from the theoretical modeling perspective, have a tendency to behave indifferently toward their work and their organization and thus, they are expected to demonstrate low work performance and little support of their organization (Griffeth et al., 1999). The other three categories of employees seem to generally offer some degree of positive contribution to their job and/or their organization: Stars contribute positively to both; Lone Wolves contribute positively to their jobs, and Corporate Citizens contribute positively to their organization. Therefore, managers might want to know, following the traditional attitude $\rightarrow$ behavioral paradigm, the impact of positive or negative attitude changes on Apathetic mobility and which of the two attitudes, if changed, has the greater impact on this mobility. Consequently, one pragmatic purpose by employing sensitivity analysis to make small positive changes and then small negative changes in job involvement and affective commitment and then to repeat the two changes for both variables simultaneously is to determine how many employees will leave or enter the Apathetic's employee category.

A second pragmatic purpose for the sensitivity analysis is to determine which of the two attitudinal variables, job involvement or affective commitment, has the greatest power to influence the Apathetic's mobility. Ultimately, the pragmatic outcome of this study would be to know which of these two variables a manager could exert the least amount of energy and resources on in order to cause the greatest movement of Apathetics into one of the other three more desirable categories.

As previously stated, sensitivity analysis is a technique to artificially manipulate data on key variables (Fischoff et al. 1979; Wallace, 2000) and since it has not previously been applied to any employee category models, we start with our modeling assumptions. Our three main assumptions are: (1) there are some employees who exhibit "hard core" attitudes and are not likely to change their attitudes and position within their category; (2) there are some employees who have "soft core" attitudes and these borderline employees are likely to change their attitudes, thus resulting in movement into another employee category; and (3) even though we cannot specifically predict an employee's movement, we can predict general direction of movement. For example, we know from Figure 1 that if job involvement responses were increased by 1 unit past its median scale, borderline employees who moved out of the Corporate Citizen category would have to generally move into the Star category or alternatively, Apathetics who moved would have to generally move into the Lone Wolves category. There are employees who are on the borderline between two categories and with the subsequent change in their responses, it would be hard to predict which specific category movement they would make. The resultant effects of our assumptions and the lack of prior use of sensitivity analysis on employee category models makes this study purely exploratory and, thus, no hypotheses or propositions are presented. 


\section{Methodology}

\section{Sample and Data Collection}

A sample population of 553 non-managerial employees was taken from a respondent pool of 689 participating employees of a national transportation firm having a total employment of 1300 at the time of the survey. Management employees $(n=103)$ were deleted from the data set and a list-wise deletion was performed by SPSS to yield 553 complete and usable surveys. These respondents came from six different centers operated by the organization across the country, as well as, its corporate headquarters and included office clerical and professional personnel. Demographically, the sample included 42 percent females, 58 percent males, 65 percent were aged 40 or younger and 32 percent had a college degree.

The survey was kept anonymous at the company's request such that there was no coding for name, location, position in the company, or company division. A survey form, cover letter, directions, and a postage-paid return envelope made up the respondent package.

\section{Measures}

Affective commitment was measured with an eight-item scale from Meyer and Allen (1984) employing a five-point Likert scale $(1=$ strongly disagree to $5=$ strongly agree). Sample items included "I enjoy discussing my organization with people outside of it" and "This organization has a great deal of personal meaning for me." The Cronbach (1951) alpha internal reliability coefficient was .88 .

Job involvement was measured with the ten-item Job Involvement Scale developed by Kanungo (1982). This scale measures the degree of psychological importance of one's job using a five-point Likert scale $(1=$ strongly disagree to $5=$ strongly agree). Sample items included "I consider my job to be very central to my existence" and "I am very much personally involved in my job." The internal reliability alpha coefficient was .86.

\section{Modeling Formulations}

To create the categories described by Blau and Boal (1987), past work using the model has focused on creating a four-cell matrix where affective commitment and job involvement were split into a "high" and "low" groups using the scale median as the boundary (Blau \& Boal, 1987: 292). In this study, the categorization procedure was done using scale score quartiles. This had the effect of creating a 16-cell rather than 4cell matrix. This consecutively numbered 16-cell matrix thus allows for each of the four employee categories to be further divided into four sub-sets (see Figure 2). The employees of greatest concern in this research are those who are on the cusp of each employee category or per Figure 2, those on the median splits of the two variables and, thus, were assumed to be the employees who are borderline in that category. According 
to one of our initial assumptions, "hard core" employees at the polar extremes of the scales and farthest from the median scale values would probably not change categories with only small changes in their attitudes. Figure 3 shows a scatter plot of the 16-cell matrix and identifies the scale's quartiles used to define the sixteen cells and ultimately the distribution of employees across the sixteen cells.

The specific quartile values defining the sixteen cells and respective employee categories are defined in Table 1. The respective "hard core" employees in this table are 18 Apathetics (cell 1), 12 Stars (cell 16), 2 Corporate Citizens (cell 7), and 0 Lone

Figure 2

\section{Sixteen-Cell Matrix Across Four Employee Groups}

Affective

Commitment Median Split $=24$

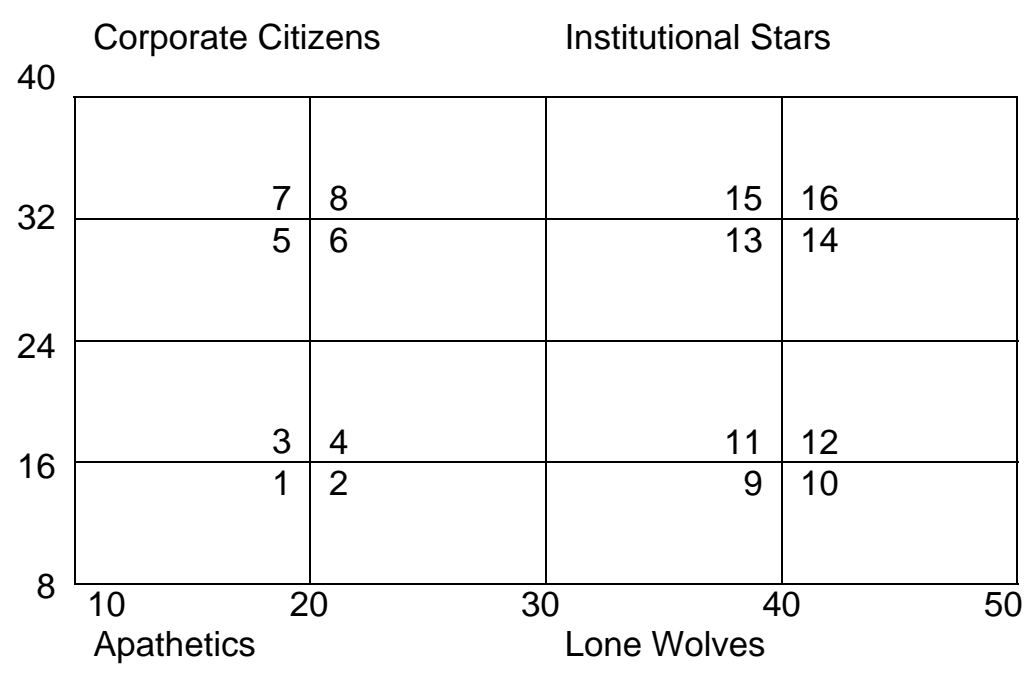

Job Involvement Median Split $=30$

Figure 3

Distribution of Respondents on 16-Cell Matrix

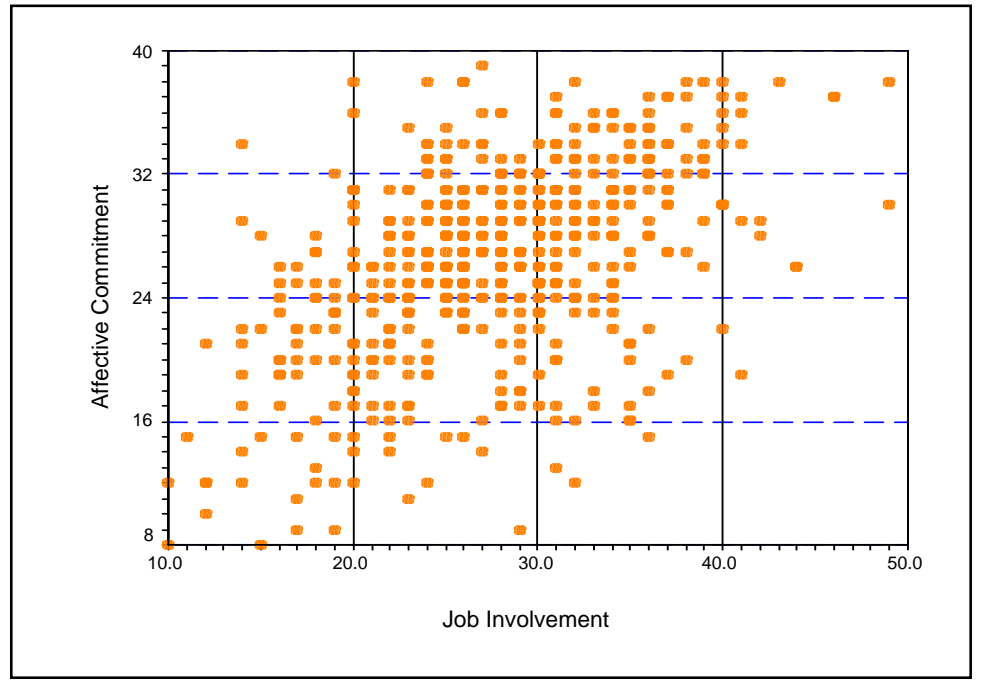


Table 1

Scale Quartile Scores Used to Define Categories

\begin{tabular}{|c|l|c|c|c|c|}
\hline Cell & \multicolumn{1}{|c|}{ Category } & $\begin{array}{c}\text { Affective } \\
\text { Commitment } \\
\text { Score }\end{array}$ & $\begin{array}{c}\text { Job } \\
\text { Involvement } \\
\text { Score }\end{array}$ & $\begin{array}{c}\text { Respondents } \\
\text { per Category }\end{array}$ & $\begin{array}{c}\text { Percentage of } \\
\text { Respondents per } \\
\text { Category }\end{array}$ \\
\hline 1 & Apathetic & $0-15$ & $0-19$ & 18 & 3.3 \\
\hline 2 & Apathetic & $0-15$ & $20-29$ & 11 & 2.0 \\
\hline 3 & Apathetic & $16-23$ & $0-19$ & 26 & 4.7 \\
\hline 4 & Apathetic & $16-23$ & $20-29$ & 60 & 10.8 \\
\hline 5 & Corporate Citizen & $24-31$ & $0-19$ & 15 & 2.7 \\
\hline 6 & Corporate Citizen & $24-31$ & $20-29$ & 168 & 30.4 \\
\hline 7 & Corporate Citizen & $32+$ & $0-19$ & 2 & .4 \\
\hline 8 & Corporate Citizen & $32+$ & $20-29$ & 34 & 6.1 \\
\hline 9 & Lone Wolf & $0-15$ & $30-39$ & 3 & .5 \\
\hline 10 & Lone Wolf & $0-15$ & $40+$ & 0 & 0 \\
\hline 11 & Lone Wolf & $16-23$ & $30-39$ & 28 & 5.1 \\
\hline 12 & Lone Wolf & $16-23$ & $40+$ & 2 & .4 \\
\hline 13 & Institutional Star & $24-31$ & $30-39$ & 102 & 18.4 \\
\hline 14 & Institutional Star & $24-31$ & $40+$ & 9 & 1.6 \\
\hline 15 & Institutional Star & $32+$ & $30-39$ & 63 & 11.4 \\
\hline 16 & Institutional Star & $32+$ & $40+$ & 12 & 2.2 \\
\hline
\end{tabular}

Wolves (cell 10). These employees are assumed to be steadfast in their attitudes and thus, will remain in their respective employee category; however, the remaining employees are subject to attitude change and thus, some degree of movement.

\section{Sensitivity Analysis}

The type of sensitivity analysis used in this study represents a simple, rudimentary sensitivity analysis approach rather than a more formal, linear programming approach (Frey \& Patil, 2002; Wallace, 2000). Its use is to investigate the employees who are on the cusp or near the median scores of the two attitudinal variables and therefore, are the most likely to move to another employee category should their attitude change. The minimum attitude change for an employee would be to change their scale response on just one of the eighteen questions used in the study. This would also represent the smallest change that a manager might do to help change the employee's attitude.

Therefore, the following two data manipulations were utilized. First, the employee's response data were increased and then decreased by 1 unit for each separate attitudinal variable and then increased/decreased for both variables simultaneously. Performing these data manipulations would serve the pragmatic purposes of identifying how many employees left or entered the Apathetic category and which variable had the greatest power to influence the employees' mobility.

The second manipulation utilized a 5 percent rather than a 1 unit change in the variables, both individually and simultaneously. The underlying rationale for this 
manipulation was that managers may also be interested in identifying what percentage of employees might move to different categories given a percentage scale change in their attitudes. However, remember that the mobility of borderline employees is the central interest and that managers want to make the smallest change possible, which is to change attitudes by one scale difference. Given that the median scale for borderline job involved employees was 30 and the median for borderline affective committed employees was 24 , a five percent change was the minimum to produce a one unit scale change. Utilizing the 5 percent manipulation also allowed investigation of the two pragmatic purposes of the study and provided an alternative approach to be compared with the 1 unit change.

The following six sensitivity analyses were subsequently performed.

Analysis 1. Increasing (decreasing) each employee's affective commitment scale score by 1.

Analysis 2. Increasing (decreasing) each employee's job involvement scale score by 1. Analysis 3. Increasing (decreasing) both employee's affective commitment scale score and job involvement scale score by 1 each.

Analysis 4. Increasing (decreasing) each employee's affective commitment scale score by 5 percent.

Analysis 5. Increasing (decreasing) each employee's job involvement scale score by 5 percent.

Analysis 6. Increasing (decreasing) both employee's affective commitment scale score and job involvement scale score by 5 percent each.

\section{Results}

The results of the six different sensitivity analyses are presented below.

\section{Analysis 1 - Increasing/Decreasing Affective Commitment Scale Score by 1 Unit}

Table 2 shows that if all the employee's scale scores had been one value higher $(+1)$ the result would have moved 21 employees in total. The number of Apathetics would have dropped from 115 to 100 or in percentage terms, the number of Apathetics would have reduced from 20.8 percent to 18.1 percent or a -13 percent drop (2.7 percentage point drop) in the total number of Apathetics. Lone wolves would have dropped from 33 to 27 or from 6 percent to 5 percent, a -16.7 percent drop. The numbers of Stars and Corporate Citizens increase by 6 and 15, respectively, resulting in a 3.3 percent increase for the former and a 6.8 percent increase for the latter.

The effect of decreasing, rather than increasing, the affective commitment score by 1 unit has a significantly more dramatic effect. The number of Apathetics increases 25.2 percent $(n=+29)$ from the original number in the category and the number of Lone Wolves increases 29.5 percent $(n=+10)$. The number of Corporate Citizens drops by 13.3 percent $(n=-29)$ and the Stars lose -6.9 percent $(n=-13)$ of the employees originally classified. 
Table 2

Effect of Increasing/Decreasing Affective Commitment Score by 1 Unit

\begin{tabular}{|l|c|c|c|c|c|c|c|c|}
\hline & $\begin{array}{c}\text { Number of } \\
\text { Employees } \\
\text { per } \\
\text { Category }\end{array}$ & $\begin{array}{c}\text { Original } \\
\text { Data }\end{array}$ & $\begin{array}{c}\text { "+"1 Added } \\
\text { to Affcomt } \\
\text { Score Only }\end{array}$ & $\begin{array}{c}\text { \% Change } \\
\text { from } \\
\text { Original } \\
\text { Data }\end{array}$ & $\begin{array}{c}\text { Numerical } \\
\text { Change }\end{array}$ & $\begin{array}{c}\text {-1" } \\
\text { Scobtracted } \\
\text { From } \\
\text { Affcomt } \\
\text { Score Only }\end{array}$ & $\begin{array}{c}\text { Change } \\
\text { from } \\
\text { Original } \\
\text { Data }\end{array}$ & $\begin{array}{c}\text { Numerical } \\
\text { Change* }\end{array}$ \\
\hline Apathetics & 115 & $20.8 \%$ & $18.1 \%$ & $-13.0 \%$ & $(15)$ & $26.0 \%$ & $25.2 \%$ & 29 \\
\hline Corporate Citizen & 219 & $39.6 \%$ & $42.3 \%$ & $6.8 \%$ & 15 & $34.4 \%$ & $-13.3 \%$ & $(29)$ \\
\hline Lone Wolf & 33 & $6.0 \%$ & $5.0 \%$ & $-16.7 \%$ & $(6)$ & $7.8 \%$ & $29.5 \%$ & 10 \\
\hline Star & 186 & $33.6 \%$ & $34.7 \%$ & $3.3 \%$ & 6 & $31.3 \%$ & $-6.9 \%$ & $(13)$ \\
\hline & 553 & $100.0 \%$ & $100.1 \%$ & & & $99.4 \%$ & & \\
\hline
\end{tabular}

${ }^{*}$ The difference between the number employees leaving and entering categories in this table and following tables is due to percentage rounding errors.

Analysis 2 - Increasing/Decreasing Job Involvement Scale Scores by 1 Unit

A unitary change in the employee's job involvement score moved -7.2 percent $(n=-8)$ out of the Apathetics and -9.1 percent $(n=-20)$ out of the Corporate Citizens category (see Table 3). The Lone Wolves and Stars increases by like numeric amounts with the percentage changes being +25 percent for Lone Wolves and +11 percent for Stars.

Decreasing one unit from their scale scores moved -16 percent $(n=-30)$ people out of the Stars category. The number of Apathetics increased by 5.2 percent $(n=+6)$. The numbers in the Corporate Citizen category grew 13.2 percent $(n=+29)$ and the numbers of Lone Wolves dropped by -18.6 percent $(n=-6)$.

Table 3

Effect of Increasing/Decreasing Job Involvement Scale Score by 1 Unit

\begin{tabular}{|l|c|c|c|c|c|c|c|c|}
\hline & $\begin{array}{c}\text { Number of } \\
\text { Employees } \\
\text { per } \\
\text { Category }\end{array}$ & $\begin{array}{c}\text { Original } \\
\text { Data }\end{array}$ & $\begin{array}{c}\text { "+1" Added } \\
\text { to J.I. } \\
\text { Score Only }\end{array}$ & $\begin{array}{c}\% \text { Change } \\
\text { from } \\
\text { Original } \\
\text { Data }\end{array}$ & $\begin{array}{c}\text { Numerical } \\
\text { Change }\end{array}$ & $\begin{array}{c}\text { Subtracted } \\
\text { From J.I. } \\
\text { Score Only }\end{array}$ & $\begin{array}{c}\% \text { Change } \\
\text { from } \\
\text { Original } \\
\text { Data }\end{array}$ & $\begin{array}{c}\text { Numerical } \\
\text { Change }\end{array}$ \\
\hline Apathetics & 115 & $20.8 \%$ & $19.3 \%$ & $-7.2 \%$ & $(8)$ & $21.9 \%$ & $5.2 \%$ & 6 \\
\hline Corporate Citizen & 219 & $39.6 \%$ & $36.0 \%$ & $-9.1 \%$ & $(20)$ & $44.8 \%$ & $13.2 \%$ & 29 \\
\hline Lone Wolf & 33 & $6.0 \%$ & $7.5 \%$ & $25.0 \%$ & 8 & $4.9 \%$ & $-18.6 \%$ & $(6)$ \\
\hline Star & 186 & $33.6 \%$ & $37.3 \%$ & $11.0 \%$ & 20 & $28.2 \%$ & $-16.0 \%$ & $(30)$ \\
\hline & 553 & $100.0 \%$ & $100.1 \%$ & & & $99.8 \%$ & & \\
\hline
\end{tabular}

Analysis 3 - Increasing/Decreasing Both Scales by 1 Unit

Increasing the scores by one unit on both attitudinal measures increased the number of Stars by 14.9 percent $(n=+28)$ and the number of Lone Wolves by 1.7 percent $(n=+1)$. The number of Apathetics decreased by -19.2 percent $(n=-22)$. The number of Corporate Citizens was reduced by -2.8 percent $(n=-6)$. 
When one unit decreased both employees' scores, the number of Apathetics and Stars were most affected. Stars fell by -20.3 percent $(n=-38)$ and Apathetics increased by 32.1 percent $(n=+37)$. The numbers of Corporate Citizens fell by -.9 percent $(n=-2)$ and Lone Wolves grew by 5.5 percent $(n=+2)$.

The greatest impact of changing both job involvement and affective commitment occurred in the Star and Apathetic categories and the greatest changes resulted when both scale scores were lowered by one unit.

\section{Table 4}

\section{Effect of Increasing/Decreasing Both Job Involvement and Affective Commitment Scale Scores by 1 Unit}

\begin{tabular}{|l|c|c|c|c|c|c|c|c|}
\hline & $\begin{array}{c}\text { Number of } \\
\text { Employees } \\
\text { per } \\
\text { Category }\end{array}$ & $\begin{array}{c}\text { Original } \\
\text { Data }\end{array}$ & $\begin{array}{c}\text { "+"1 Added } \\
\text { to J.I. And } \\
\text { Afftcomt }\end{array}$ & $\begin{array}{c}\text { \% Change } \\
\text { from } \\
\text { Original } \\
\text { Data }\end{array}$ & $\begin{array}{c}\text { Numerical } \\
\text { Change }\end{array}$ & $\begin{array}{c}\text { "-1" } \\
\text { Subtracted } \\
\text { From J.I. } \\
\text { And } \\
\text { Afftcomt }\end{array}$ & $\begin{array}{c}\% \text { Change } \\
\text { from } \\
\text { Original } \\
\text { Data }\end{array}$ & $\begin{array}{c}\text { Numerical } \\
\text { Change }\end{array}$ \\
\hline Apathetics & 115 & $20.8 \%$ & $16.8 \%$ & $-19.2 \%$ & $(22)$ & $27.5 \%$ & $32.1 \%$ & 37 \\
\hline Corporate Citizen & 219 & $39.6 \%$ & $38.5 \%$ & $-2.8 \%$ & $(6)$ & $39.2 \%$ & $-0.9 \%$ & $(2)$ \\
\hline Lone Wolf & 33 & $6.0 \%$ & $6.1 \%$ & $1.7 \%$ & 1 & $6.3 \%$ & $5.5 \%$ & 2 \\
\hline Star & 186 & $33.6 \%$ & $38.6 \%$ & $14.9 \%$ & 28 & $26.8 \%$ & $-20.3 \%$ & $(38)$ \\
\hline & 553 & $100.0 \%$ & $100.0 \%$ & & & $99.8 \%$ & & \\
\hline
\end{tabular}

The remaining three sensitivity analyses indicate the employee category change created by the 5 percent score change. Changes in the affective commitment scores were done first.

\section{Analysis 4 - Increasing/Decreasing Affective Scale Scores by 5 Percent}

Similar results were found in this treatment as were found in the previously-mentioned unitary scale scores of affective commitment. In Table 5, the numbers of Apathetics and Lone Wolves decreased while the Corporate Citizens and Stars increased, and, by like amounts. Increasing affective commitment reduced the numbers of Apathetics by -13 percent $(n=-15)$ and Lone Wolves by -18.3 percent $(n=-6)$. The Corporate Citizens gained 6.8 percent $(n=+15)$ and the Stars gained 3.3 percent $(n=+6)$.

When 5 percent was subtracted from the affective commitment scale scores, the number of Apathetics increased by 48.7 percent $(n=+56)$ and the Lone Wolves by 68.8 percent $(n=+23)$. Corporate Citizens dropped by -25.6 percent $(n=-56)$ and Stars by 13.9 percent $(n=-26)$. The outcome of a 5 percent decrease in affective commitment resulted in almost four times the movement of people out of and into other categories than did a 5 percent increase. 
Table 5

Increasing (Decreasing) Affective Commitment Scale Score by 5 Percent

\begin{tabular}{|l|c|c|c|c|c|c|c|c|}
\hline Employee Category & $\begin{array}{c}\text { Number of } \\
\text { Employees } \\
\text { per } \\
\text { Category }\end{array}$ & $\begin{array}{c}\text { Original } \\
\text { Data }\end{array}$ & $\begin{array}{c}5 \% \text { Added to } \\
\text { Affcomt } \\
\text { Score Only }\end{array}$ & $\begin{array}{c}\% \text { Change } \\
\text { from } \\
\text { Original } \\
\text { Data }\end{array}$ & $\begin{array}{c}\text { Numerical } \\
\text { Change }\end{array}$ & $\begin{array}{c}5 \% \\
\text { Subtracted } \\
\text { from Affcomt } \\
\text { Score Only }\end{array}$ & $\begin{array}{c}\% \text { Change } \\
\text { from } \\
\text { Original } \\
\text { Data }\end{array}$ & $\begin{array}{c}\text { Numerical } \\
\text { Change }\end{array}$ \\
\hline Apathetics & 115 & $20.8 \%$ & $18.1 \%$ & $-13.0 \%$ & $(15)$ & $30.9 \%$ & $48.7 \%$ & 56 \\
\hline Corporate Citizen & 219 & $39.6 \%$ & $42.3 \%$ & $6.8 \%$ & 15 & $29.5 \%$ & $-25.6 \%$ & $(56)$ \\
\hline Lone Wolf & 33 & $6.0 \%$ & $4.9 \%$ & $-18.3 \%$ & $(6)$ & $10.1 \%$ & $68.8 \%$ & 23 \\
\hline Star & 186 & $33.6 \%$ & $34.7 \%$ & $3.3 \%$ & 6 & $28.9 \%$ & $-13.9 \%$ & $(26)$ \\
\hline & 553 & $100.0 \%$ & $100.0 \%$ & & & $99.5 \%$ & & \\
\hline
\end{tabular}

Analysis 5 - Increasing/Decreasing Job Involvement by 5 Percent

When job involvement changed by +5 percent the numbers of Apathetics and Corporate Citizens decreased by -7.2 percent $(n=-8)$ and -9.1 percent $(n=-20)$, respectively (see Table 6). The population of Lone Wolves and Stars increased by like amounts.

Adding 5 percent resulted in 28 people moving into different categories, but subtracting 5 percent resulted in 65 employees changing categories; a 2.3 fold increase in movement resulting from a relatively small change in the negative direction. This represents a 13.2 percent move in the entire employee base. As occurred with affective commitment, the changes in job involvement are most dramatic in the negative direction.

Table 6

Increasing/Decreasing Job Involvement by 5 Percent

\begin{tabular}{|l|c|c|c|c|c|c|c|c|}
\hline Employee Category & $\begin{array}{c}\text { Number of } \\
\text { Employees } \\
\text { per } \\
\text { Category }\end{array}$ & $\begin{array}{c}\text { Original } \\
\text { Data }\end{array}$ & $\begin{array}{c}5 \% \text { Added } \\
\text { to J.I. } \\
\text { Score Only }\end{array}$ & $\begin{array}{c}\text { Change } \\
\text { from } \\
\text { Original } \\
\text { Data }\end{array}$ & $\begin{array}{c}\text { Numerical } \\
\text { Change }\end{array}$ & $\begin{array}{c}5 \% \\
\text { Subtracted } \\
\text { From J.I. } \\
\text { Score Only }\end{array}$ & $\begin{array}{c}\% \text { Change } \\
\text { from } \\
\text { Original } \\
\text { Data }\end{array}$ & $\begin{array}{c}\text { Numerical } \\
\text { Change }\end{array}$ \\
\hline Apathetics & 115 & $20.8 \%$ & $19.3 \%$ & $-7.2 \%$ & $(8)$ & $23.0 \%$ & $10.4 \%$ & 12 \\
\hline Corporate Citizen & 219 & $39.6 \%$ & $36.0 \%$ & $-9.1 \%$ & $(20)$ & $49.2 \%$ & $24.2 \%$ & 53 \\
\hline Lone Wolf & 33 & $6.0 \%$ & $7.4 \%$ & $23.3 \%$ & 8 & $3.8 \%$ & $-36.7 \%$ & $(12)$ \\
\hline Star & 186 & $33.6 \%$ & $37.3 \%$ & $11.0 \%$ & 20 & $24.1 \%$ & $-28.4 \%$ & $(53)$ \\
\hline & 553 & $100.0 \%$ & $100.0 \%$ & & & $100.0 \%$ & & \\
\hline
\end{tabular}

Analysis 6 - Increasing/Decreasing Affective Commitment and Job Involvement Scale Scores by 5 Percent

Adding to both the job involvement and the affective commitment scores by 5 percent produced changes that decreased the population of Apathetics by -19.2 percent; ( $n=-$ 22) and Corporate Citizens by -2.8 percent $(n=-6)$ (see Table 7). When the scores were reduced 5 percent, there were significantly more people changing categories. Reducing both scores by 5 percent resulted in almost three to four times more people changing categories than when the scores were increased by 5 percent. The number of 
Apathetics increases over the original data by 70.4 percent $(n=+81)$ and the number of Stars drops by -33.8 percent $(n=-63)$. The Lone Wolves drop by -6.6 percent $(n=-2)$.

This shift of 81 people into the Apathetic category represents a 14.6 percent shift in the total workforce, thus swelling the ranks of the Apathetics to 196 or 35.4 percent of the total number employees. The number of Stars dropped from 186 employees (33.6 percent of the workforce) to 158 employees (28.6 percent of the workforce).

Table 7

Increasing/Decreasing Affective Commitment and Job Involvement Scale Scores by 5 Percent

\begin{tabular}{|l|c|c|c|c|c|c|c|c|}
\hline & $\begin{array}{c}\text { Number of } \\
\text { Employees } \\
\text { per } \\
\text { Category }\end{array}$ & $\begin{array}{c}\text { Original } \\
\text { Data }\end{array}$ & $\begin{array}{c}\text { 5\% Added } \\
\text { to Both } \\
\text { J.I. And } \\
\text { Affcomt } \\
\text { Scores }\end{array}$ & $\begin{array}{c}\text { \% Change } \\
\text { from } \\
\text { Original } \\
\text { Data }\end{array}$ & $\begin{array}{c}\text { Numerical } \\
\text { Change }\end{array}$ & $\begin{array}{c}\text { Subtracted } \\
\text { from Both } \\
\text { J.I. And } \\
\text { Affcomt } \\
\text { Scores }\end{array}$ & $\begin{array}{c}\text { Change } \\
\text { from } \\
\text { Original } \\
\text { Data }\end{array}$ & $\begin{array}{c}\text { Numerical } \\
\text { Change }\end{array}$ \\
\hline Apathetics & 115 & $20.8 \%$ & $16.8 \%$ & $-19.2 \%$ & $(22)$ & $35.4 \%$ & $70.4 \%$ & 81 \\
\hline Corporate Citizen & 219 & $39.6 \%$ & $38.5 \%$ & $-2.8 \%$ & $(6)$ & $36.7 \%$ & $-7.3 \%$ & $(16)$ \\
\hline Lone Wolf & 33 & $6.0 \%$ & $6.2 \%$ & $3.3 \%$ & 1 & $5.6 \%$ & $-6.6 \%$ & $(2)$ \\
\hline Star & 186 & $33.6 \%$ & $38.6 \%$ & $14.9 \%$ & 28 & $22.2 \%$ & $-33.8 \%$ & $(63)$ \\
\hline & 553 & $100.0 \%$ & $100.1 \%$ & & & $100.0 \%$ & & \\
\hline
\end{tabular}

The use of sensitivity analysis takes a "what if" approach and suggests that affective commitment would be the attitude to focus on if the manager's choice of potentially impacting employees' behavior was between just affective commitment and job involvement. Though it was not the purpose of this study to investigate anything other than the extent of movement from one employee category to another, the question does arise about the predictive impact of affective commitment's versus job involvement's impact on desirable employee outcomes.

As an additional analysis of which attitude had the greatest predictive impact on employee outcomes, three outcome variables measured in this study were analyzed using regression analysis. The results of three regression analyses of affective commitment and job involvement on trust, job satisfaction, and intent to stay, respectively, supported the predictive impact of affective commitment over job involvement. Affective commitment produced significant unstandardized beta coefficients on trust $(b=.34, t=13.43, p=.00)$, job satisfaction $(b=.41, t=12.91, p=$ $.00)$, and intent to stay $(b=.24, t=14.13, p=.00)$. Job involvement produced insignificant results on trust $(b=-.03, t=-1.26, p=.08)$, job satisfaction $(b=.11, t=$ $1.74, p=.08)$, and intent to stay $(b=-.06, t=-1.68, p=.09)$. Both analyses support affective commitment over job involvement as the primary attitude change variable for the manager to influence employee outcomes. Regression analysis supports this direction of change, but the focus of this study is on how many employees can a manager influence to change employee categories. Sensitivity analysis provides a sense of the magnitude and direction of the change, that is, the number of employees 
affected by the influence attempt and which employee category gains and loses membership.

\section{Discussion and Managerial Implications}

The findings from this study and their managerial implications are inherently linked together. The particular pragmatic focus of this study was to question which is the best attitudinal change approach, trying to influence job involvement or affective commitment, when it comes to moving as many Apathethic employees out of that category while simultaneously keeping as many employees as possible from moving into the Apathetic category. By utilizing Blau and Boal's (1987) model, four employee categories were created as the result of the two attitudinal variables' interaction. Three of these employee categories contain employees who provide some form of positive, contributive behavior to the workplace, while the fourth category, Apathetics, seems not to do so, or at least, far less that the other categories. Therefore, the managerial implications of the findings from this study will help the manager to better understand and predict whether job involvement or affective commitment, if increased, will reduce the number of Apathetic employees or alternatively, if decreased, will increase the number of Apathetic employees. The number of employees who are borderline in their category making a transition to a new category and the percentage change in category populations are key considerations in addressing the purposes of this study.

Clearly, if managers had sufficient time and resources to devote to increasing both job involvement and affective commitment attitudinal change, the number and percentage of Apathetic employees moving to the other three categories would be the greatest. Likewise, if managers did nothing to try to increase both attitudes, but instead employees decreased their attitudes on both variables, the number and percentage of Apathetic employees would increase dramatically.

From a sensitivity analysis perspective, the pragmatic purpose is to minimize the manager's attitudinal change interaction with the employee. Managers are assumed to have limited time and resources in which to attempt attitude change and therefore, they must decide which tactics to implement in order to achieve the greatest positive result or the least negative result. Thus, the manager has to decide whether to focus on trying to change the attitude of employees regarding their thoughts about their job or their commitment to their organization. This is an especially important decision regarding Apathetic employees, who have low attitudes about both their jobs and organization.

The findings from the study suggest managers could move more Apathetic employees into the other three employee categories by focusing on an employee's affective commitment. Furthermore, a shift of just one unit negatively on this attitude by employees causes a tremendous influx of employees into the Apathetic category.

The overall conclusions within this organization, based on the sensitivity analysis minimization criterion, is that managers should concentrate on increasing the affective commitment attitude of their borderline Apathetic employees in order to cause them to 
move into other employee categories. The other overall conclusion is that if managers do things that help decrease the affective commitment attitude of other non-Apathetic employees by even very small amounts, there will be substantial movement of these employees into the Apathetic category. Such a result would bring with it the concomitant changes in behavior such as attendance problems, lower productivity, poorer participation, and a more disruptive organization environment associated with employees having these poorer attitudes as suggested by Griffeth, Gaertner, and Sager (1999) and Blau and Boal (1987).

\section{Limitations and Future Research}

This research utilized an applied field case study which was then subjected to sensitivity analyses. This type of research typically has a number of limitations cited in the literature (Scandura and Williams 2000). First, it was presumed to be low on precision of measurement, however, in this study, the precision of measurement is high given the use of highly reliable and valid measures. Second, this approach is limited to low control of behavioral variables. This study is a field study and not an experimental study. As a field study it does rate high on realism of context (Scandura and Williams 2000) and thus, managerial attempts to influence employees' behaviors can have realistic consequences. Third, this research approach has low generalizability. The findings from this study should be generalized cautiously and subsequent studies in other types of organizations and industries may suggest modified or expanded findings.

Additionally, post hoc sensitivity analysis, especially without testable hypotheses, may be subject to validity issues in which the findings are obtained through "fishing and error" (Cook and Campbell 1979). However, this study was an exploratory study and thus, devoid of testable hypotheses due to the lack of previous research in the area. Furthermore and implicit in the sensitivity analysis method is the need to experiment (play "what if" games) to find out how an output is affected by variations in input variables (Geldermann and Rentz 2001). In addition, this research was characterized by a limited, rather than unlimited, number of specific score changes. The amounts and percentages of employee movement caused by the limited specific score changes was not subjected to statistical significance testing. Therefore, no indication of statistically significant movement of employees was made.

Finally, this study has investigated changes to two attitudinal variables, but has not suggested tactics or strategies to increase either one of these variables. There have been various approaches developed mainly in the job redesign literature (Hackman, 1976; Hackman \& Oldham, 1980) to influence job involvement attitudes, as well as alternative approaches developed in the organizational commitment literature (Caldwell, Chatman, \& O'Reilly, 1990; Meyer \& Allen, 1997; Mowday, Porter, \& Steers, 1988) to influence affective commitment. Future research might duplicate these findings and extend their presentation of results by including and updating strategies to influence these two variables. 


\section{Conclusion}

What this all suggests to managers is that affective commitment has greater leverage on employees' attitudes than does job involvement when it comes to impacting Apathetic employee mobility. Therefore, by focusing on strengthening affective commitment rather than job involvement, managers would produce the most beneficial changes in attitude and accompanying employee's behavior. However, negatively impacting an employee's affective commitment would produce dramatic changes in attitudes and subsequent behaviors as more employees would become apathetic.

\section{References}

Ajzen, I. (2001). Nature and operations of attitudes. In S. T. Fiske, D. L. Schacter \& C. Zahn-Waxler (Eds.), Annual Review of Psychology. Palo Alto, CA: Annual Reviews, Inc., 52, 27-58.

Ajzen, I. (1996). The directive influence of attitudes on behavior. In M. Gollwitzer \& J. A. Bargh (Eds.), The Psychology of Action: Linking Cognition and Motivation to Behavior. New York: Guilford, 385-403.

Allen, N., \& Meyer, J. (1990). Organizational socialization tactics: A longitudinal analysis of links to newcomers' commitment and role orientation. Academy of Management Journal, 33(4), 847-859.

Blau, G. J. (1986). Job involvement and organizational commitment as interactive predictors of tardiness and absenteeism. Journal of Management, 12, 577-584.

Blau, G., \& Boal, K. (1987). Conceptualizing how job involvement and organizational commitment affect turnover and absenteeism. Academy of Management Review, 12(2), 288-300.

Blau, G., \& Boal, K. (1989). Using job involvement and organizational commitment interactively to predict turnover. Journal of Management, 15(1), 115-127.

Caldwell, D. F., Chatman, J. A., \& O'Reilly, C. A. (1990). Building organizational commitment: A multifirm study. Journal of Occupational Psychology, 63, 245-261.

Casal, J. C. (1996). Shoot for the 'stars'. Journal of Health Care Marketing, 16(2), 2226.

Clinebell, S., \& Shadwick, G. (2005). The importance of organizational context on employees' attitudes: An examination of working in main offices versus branch offices. Journal of Leadership \& Organizational Studies, 11(2), 89-100. 
Cronbach, L. J. (1951). Coefficient alpha and the internal structure of tests. Psychometrika, 16, 297-334.

Cook, T. D., \& Campbell, D. T. (1979). Quasi-Experimentation: Design and Analysis Issues for Field Settings. Boston: Houghton Mifflin, 1979.

Drummond, H., \& Chell, E. (2001). Life's chances and choices-a study of entrapment in career decisions with reference to Becker's side beta theory. Personnel Review, 30(2), 186-202.

Elliott, K., \& Hall, M. (1994). Organizational commitment and job involvement: Applying Blau and Boal's typology to purchasing professionals. American Business Review, 12, 6-14.

Fischoff, B., Slovic, P., \& Lichlenstein, S. (1979). Subjective sensitivity analysis. Organizational Behavior and Human Performance, 23, 339-359.

Freund, A. (2005). Commitment and job satisfaction as predictors of turnover intentions among welfare workers. Administration in Social Work, 29(2), 5-21.

Frey, H. C., \& Patil, S. R. (2002). Identification and review of sensitivity analysis methods. Risk Analysis, 22(3), 553-578.

Gelderman, J., \& Rentz, O. (2001). Integrated technique assessment with imprecise information as a support for the identification of best available techniques (bat). ORSpektrum, 23(1), 137-157.

Griffeth, R.W., Gaertner, S., \& Sager, J.K. (1999). A taxonomic model of withdrawal behavior: The adaptive response model. Human Resource Management Review, 9(4), 557-590.

Hackman, J. R., \& Oldham, G. R. (1980). Work Redesign. Reading, MA: Addison Wesley.

Hackman, J. R. (1976). Work Design. In J. R. Hackman \& J. L. Suttle (Eds.), Improving Life at Work. Santa Monica, CA: Goodyear, 96-162.

Hirschfeld, R. R., \& Field, H.S. (2000). Work centrality and work alienation: Distinct aspects of a general commitment to work. Journal of Organizational Behavior, 21(7), 789-800.

Huselid, M. A. \& Day, N. E. (1991). Organizational commitment, job involvement, and turnover: A substantive and methodological analysis. Journal of Applied Psychology, $\underline{76}(3), 380$. 
Kanungo, R. N. (1982). Work Alienation: An Integrative Approach. New York, NY: Praeger.

Kraus, S. J. (1995). Attitudes and the prediction of behavior: A meta-analysis of the empirical literature. Personality and Social Psychology Bulletin, January, 58-75.

Leong, L., Huang, S. Y., \& Hsu, J. (2003). An empirical study on professional commitment, organizational commitment and job involvement in Canadian accounting firms. Journal of American Academy of Business, 2(2), 360-370.

Liberatore, M. J., \& Nydick, R. L. (2003). Decision Technology: Modeling, Software, and Applications. Hoboken, NJ: John Wiley \& Sons, Inc.

Madsen, S. R., Miller, D., \& John, C. R. (2005). Readiness for organizational change: Do organizational commitment and social relationships in the workplace make a difference? Human Resource Development Quarterly, 16(2), 213-233.

Martin, T. N., \& Hafer, J. C. (1995). The multiplicative interaction effects of job involvement and organizational commitment on the turnover intentions of full- and parttime employees. Journal of Vocational Behavior, 46, 310-331.

McElroy, J., Morrow, P. C., Crum, M. R., \& Dooley F. J. (1995). Railroad employee commitment and work-related attitudes and perceptions. Transportation Journal, 34(3), 13-27.

Meyer, J. P., \& Allen, N. J. (1984). Testing the side bet theory of organizational commitment: some methodological considerations. Journal of Applied Psychology, 69, 372-378.

Meyer, J. P., \& Allen, N. J. (1991). A three component conceptualization of organizational commitment. Human Resource Management Review, 1, 61-89.

Meyer, J. P., \& Allen, N. J. (1997). Commitment in the Workplace. Thousand Oaks, CA: Sage.

Mowday, R. T., Steers, R. M., \& Porter, L. W. (1979). The measurement of organizational commitment. Journal of Vocational Behavior, 14, 227-247.

Mowday, R. T., Porter, L. W., \& Steers, R. M. (1988). Employee Organizational Linkages: The Psychology of Commitment, Absenteeism, and Turnover. New York: Academic Press.

Rabinowitz, S., \& Hall, D. T. (1981). Changing correlates of job involvement in three career stages. Journal of Vocational Behavior, 18, 138-144. 
Scandura, T., \& Williams, E. (2000). Research methodology in management: Current practices, trends, and implications for future research. Academy of Management Journal, 43(6), 1248-1265.

Sutton, S. (1998). Predicting and explaining intentions and behavior: How well are we doing. Journal of Applied Social Psychology, 28, 1317-1338.

Van Dyne, L. \& Pierce, J. L. (2004). Psychological ownership and feelings of possession: Three field studies predicting employee attitudes and organizational citizenship behavior. Journal of Organizational Behavior, 25(4), 439-459.

Walker, D. \& Fox-Rushley, J. (2001). Allowing for uncertainty in economic evaluations: Qualitative sensitivity analysis. Health Policy and Planning, 16(4), 435-443.

Wallace, S. W. (2000). Decision making under uncertainty: Is sensitivity analysis of any use. Operations Research, 48(1), 20-26. 